\title{
STUDY OF DENTATE GYRUS GRANULE CELLS OF FEMALE RATS NEONATALLY TREATED
} WITH SEX HORMONES

DREKIĆ $D^{\star}$, MRVIĆ VERICA*, LOZANČE OLIVERA*, KERKEZ M**, BLAGOJEVIĆ $M^{*}$ and ZORIĆ Z*

*Faculty of Veterinary Medicine, Belgrade; ${ }^{*}$ CCS Institute Belgrade

(Received 2. February 2005)

This study was designed to determine whether adult neurogenesis occurs in the dentate gyrus of rats, and to explore the possibility that this process is regulated by the activation of sex hormones. The proliferation of hippocampal dentate gyrus granule cells was investigated using $80 \mu \mathrm{Ci}{ }^{3} \mathrm{H}$ - thymidine incorporation in the first group andin the second grouph $80 \mu \mathrm{Ci}{ }^{3} \mathrm{H}$ - thymidine and $1 \mathrm{mg}$ estrogene dipropionae. We proved the existence of a stronger proliferation of granule cells in SGZ GD in female rats. The third group of newborn female Wistar rats was treated at 4 and 8 a days of ageold, with a single dose of $2 \mathrm{mg}$ of testosterone propionate. We proved the existence of minor damages of granule cells in SGZ GD. In the fourth group, treatedat 15 days of age, a single dose of $4 \mathrm{mg}$ testosterone propionate and sacrificed when 60 days old, we proved the existence of minor damages of granular cells in SGZ GD.

Our results suggest a differential effect of sex hormones on dentate gyrus granule cells proliferation through early life in rats.

Key words: testosterone dipropionate, estrogen dipropionate, dentate gyrus, neurons, female rat

\section{INTRODUCTION}

Groups of sex steroid concentrating brain neurons are likely to be involved in the steroid feed-back mechanisms which regulate sexual behavior sexual dimorphism in the central nervous system. Each volumetrically sexually dimorphic cell group in mammals examined for gonadal hormone-binding neurons by autoradiography has been shown to exhibit labeling (Arnold and Gorski, 1984). In fact, steroid regulation of cell survival may be a common mean of generating sex differences in neuronal organization, for example, within the rodent spinal cord (Nordeen et al., 1985) or within areas of the hypothalamus (Arnold and Gorski, 1984). We have also shown complex short and long term effects of estrogen in different regions of the rat brain (Pantic and Drekic, 1982; Drekic et al., 1990; 1995a,b).

Morphogenesis of the entire hippocampal region, including dentate gyrus, in normal rats from embryonic (E) day E 10 to $E 22$ and on postnatal $(P)$ days P1, $P$ 
7 , and P 21 was extensively described and correlated with autoradiographic data (Bayer, 1980; 1982; Bayer et al., 1982). During the embryonic period, postnatally and in adulthood, granule cells proliferate, migrate and degenerate (Cameron and Gould, 1996).

Neurogenesis of rat dentate granule cells persists prenatally and postnatally up to 11 months of age and even in adults (Seki and Arai, 1995; Kuhn et al.,1996).

The proliferating, developing and adult dentate granule cells have an affinity for and depend on steroid hormones i.e. adrenal corticosteroids (Teyler et al.,1980; Jaarsma et al., 1992; Watanabe et al., 1995; Rua et al.,1995; Cameron et al., 1995; Cameron and Gould, 1996). Also, sex steroids bind to, affect and maintain both morphological and functional properties of the hippocampal region (Wooley and Mc Ewen, 1993; O'Keffe et al., 1995). Estradiol treatment in ovariectomized rats significantly increases the number of NMDA receptor binding sites within the CA1 pyramidal cells and to a lesser extent, within the granule cell somata of the dentate gyrus (Gazzaley et al., 1996). In this work we investigated postnatal development of the gyrus dentatus granular layer and its zones in neonatally estrogen treated female rats. We considered that the change in the number of dentate gyrus granule cells labeled by ${ }^{3} \mathrm{H}$-thymidine autoradiography in treated female rats indicates their reactivity to estrogen. We have also found that females treated with two small doses of Testosterone Propionate (TP) in their early neonatal period experience smaller changes then females treated with one big dose in their late neonatal period.

\section{MATERIALS AND METHODS}

Neonatal female Wistar rats (total of 20 animals) were treated with a single dose of $1 \mathrm{mg}$ of estradiol dipropionate, (ICN-Yugoslavia, Beograd), on the third day of postnatal life (P3). Simultaneously both treated (five female) and control (five female) rats were injected i/p with $80 \mu \mathrm{Ci}$ of methyl- ${ }^{3} \mathrm{H}$-thymidine (AmershamTRK 120, sp. act. $21 \mathrm{Ci} / \mathrm{mmol}$ ). The animals were killed under ether anesthesia at P 38.

\section{Autoradiographic procedure}

The brains were isolated, fixed in Bouine solution and processed for autoradiography using paraffin embedding. The hippocampal region was cut in $5 \mu \mathrm{m}$ thick, serial transverse sections which were covered with ILFORD L4 emulsion and exposed for 5 months at $4^{\circ} \mathrm{C}$. After development with KODAK 19, sections were counterstained with hematoxylin.

The number of labeled granule cells was analised in both zones of the granular layer of the suprapyramidal and infrapyramidal limbs i.e. the subgranular (SGZ) and granular zones (GZ). However, we have found it necessary to describe and investigate an additional zone of the granular layer, which we named the extragranular zone (EGZ). It is the periferal zone of the granular layer facing the molecular layer.

On each 10th section of dentate gyrus, all cells in the granular layer, including labeled ones, were counted in all fields and the number of labeled 
granule cells was estimated. In other two groups of treated female rats we have colored hippocampus remedies using hematoxylin and we have studied the changes in certain parts of gyrus dentatus. Micrographs were taken by $\mathrm{NU}_{2} \mathrm{Carl}$ Zeiss microscope Jena.

\section{RESULTS}

In newborn female control rats treated with $80 \mu \mathrm{Ci}$ of ${ }^{3} \mathrm{H}$-thymidine on the third postnatal day and sacrificed at 38 days of age(P38), labeled cells were found within both zones of the granular layer of the dentate gyrus. However, the majority of labeled cells was found in GZ.
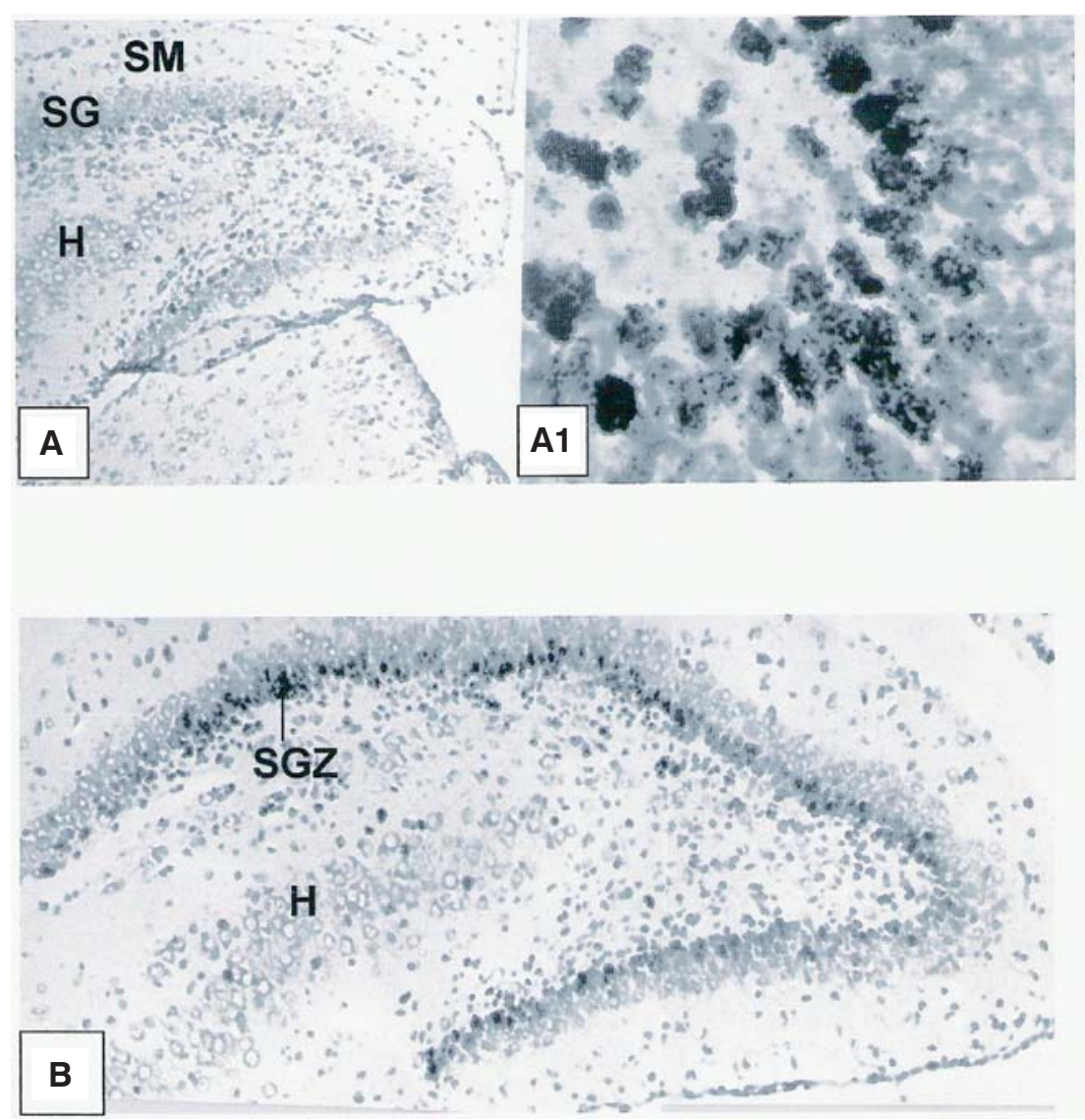

Figure 1. Dentate gyrus of 38th days old female rats

A - SM (stratum moleculare), SG (stratum granulare), $\mathrm{H}$ (hilus giry dentaty). (320x) A1 - increasing stratum granulare (400x)

$\mathrm{B}$ - SGZ -stratum granulare, H - hilus giry dentaty (320x) 
A smaller number of ${ }^{3} \mathrm{H}$-thymidine labeled cells was located deep in the granule cell layer facing the molecular layer. They had the main characteristics of dentate granule cells and in the control sections both the nucleus and cytoplasm stained paler (in control sections). However, we considered necessary to investigate these cells as a separate group and described this area as an extragranular zone (EGZ).
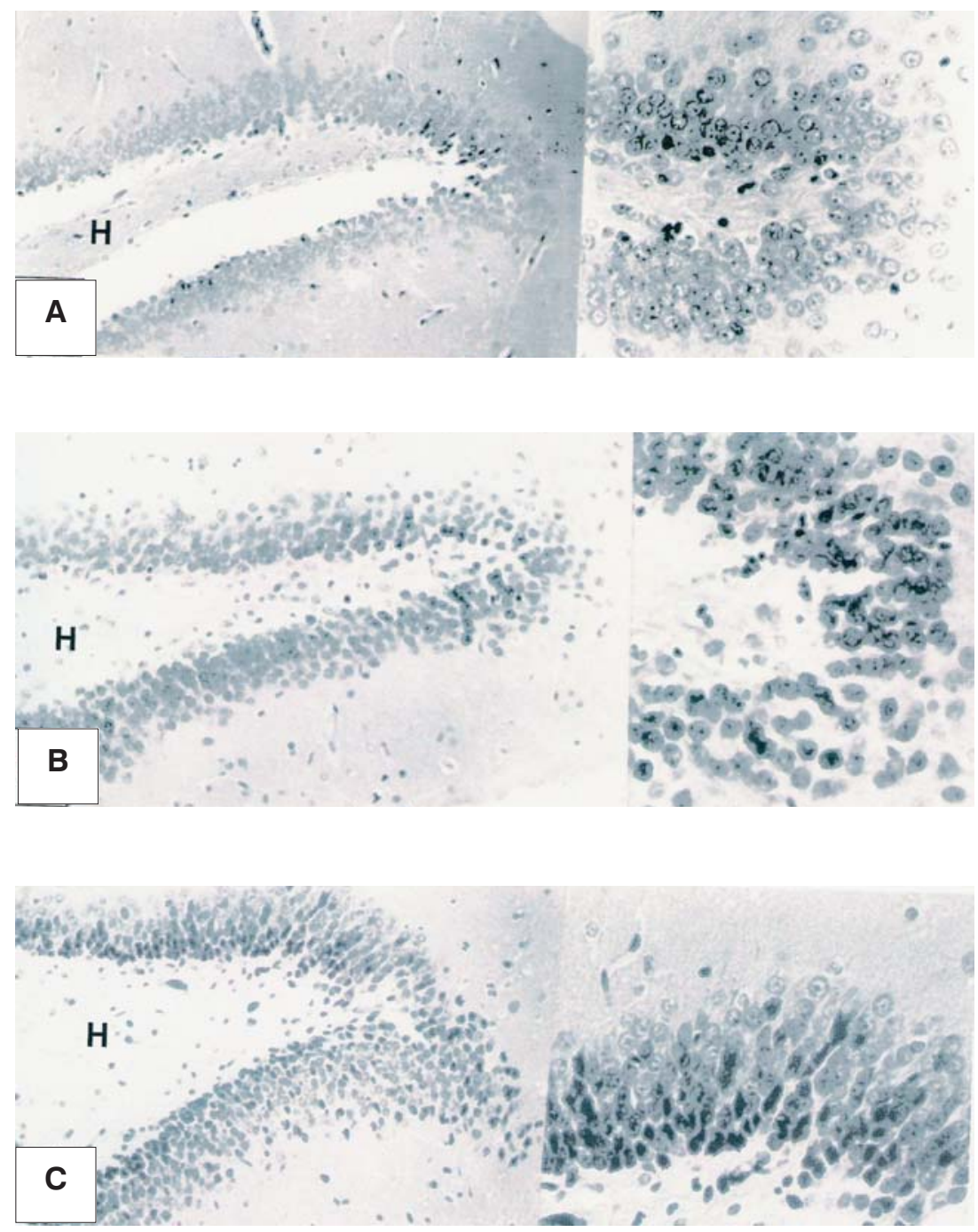

Figure 2. Dentate gyrus of 60 days old female rats

$A, B, C,-H$ - hilus giry dentaty $(150 x)$

$A 1, B 1, C 1$ - increasing stratum granulare (400x) 
In the newborn female rats treated with $80 \mu \mathrm{Ci}$ of ${ }^{3} \mathrm{H}$-thymidine and $1 \mathrm{mg}$ of estradiol on the third postnatal day (P3) and sacrificed at 38 days of life, there was an evident and significant increase in the number of labeled granule cells in the SGZ.

These cells were characterized by their small size and were darkly stained with hematoxylin in the control sections. The increased number of labeled cells was found in EGZ in both suprapyramidal and infrapyramidal limb.

Under the influence of estrogen the total population of granule cells in the suprapyramidal limb of dentate gyrus was control animals. The increased number of labeled neurons in the suprapyramidal limb was not distributed evenly in different zones.

The number of granule cells in the infrapyramidal limb also was increased. Distribution of labeled cells in different zones was higher: in SGZ and EGZ.

We have noticed that females treated with $2 \mathrm{mg}$ of TP in their 4th and 8th day of life experience smaller damages in the sub-granular layer of SGZ than females treated with $4 \mathrm{mg}$ of TP at 15th day of their life. In female rats treated with two doses of TP on day 4 and day 8 day of their neonatal life there are no important damages in SGZ GS, but the opposite is noticed in the case of female rats treated with one higher dose of TP on 15 day of neonatal life. This is where we have noticed a greater number of degenerated glya cells and neurons in SGZ both parts dentate gyrus.

\section{DISCUSSION}

The development of the hippocampal dentate gyrus of the rat was extensively described (Bayer and Altman, 1974; Bayer, 1980). Although the dentate gyrus is the last structure to appear, its origin can be followed from the early developmental stages. Cellular migration to the subventricular area in the concavity formed by the primordial Ammon's horn and subiculum at E16 and cellular accumulation in the subventricular dentate primordium at E18-E19 was described by Bayer (1980). In the developing dentate gyrus, young granule cells are initially generated exclusively in the ventricular zone. However, the newly formed proliferative center in the subgranular zone can be considered as a displaced subventricular zone of the hippocampal formation that produces both neurons and glial cells destined for the dentate gyrus during the postnatal phase of development (Nowakowski and Rakic, 1981; Sidman and Rakic, 1982; Duffy and Rakic, 1983). On E20, the ectal (suprapyramidal) limb of the granule layer appears superficial to the hilus in the anterior and posterior dentate gyrus and not in intermediate coronal sections, but on E21 and E22 becomes more distinct throughout the dentate gyrus. The ended (infrapyramidal) limb is smaller, but develops rapidly in the first few days after birth (Bayer, 1980). Furthermore, the process of naturally occurring cell death in the dentate gyrus suprapyramidal and infrapyramidal limbs has the corresponding time sequence to this described by Gould et al. (1991). The most rapid growth rate of the granule layer in the monkey occurs between E20 - E21 and continually declines thereafter (the growth rate remains high during the postnatal period, P1-P7, and between P7-P21). The 
molecular layer is not present until P1 and its development increases between P1 - P7 (Nowakowski and Rakic, 1981). In the rat and rabbit, neurogenesis in the dentate gyrus continues throughout adult life (Bayer, 1980; Bayer et al. 1982; Crespo et al.,1986; Parent et al., 1997).

During our previous investigation of neurogenesis in amygdala nuclei of neonatal rats we have also monitored the neurogenesis of the cells of dentate gyrus due to the anatomical vicinity of amygdala and hippocampal structures (Lozance,1995; Cvetković, 1995).These observations are comparable with the results reported by Bayer (1980). Present examination of dentate gyrus also represents the continuation of previous research on the influence of hormones, especially sex steroids, on amygdala and other structures of lymbic system in brain, including hippocampus. Results presented in this paper clearly indicate that estrogen caused a significant increase in the number of neurons in both, suprapyramidal and infrapyramidal limb of the dentate gyrus of treated young female rats. This increase was more pronounced in suprapyramidal limb and in labeled subpopulation of neurons than in infrapyramidal limb.

It is well known that several cell types of the rat hippocampus are targets for steroid (glucocorticoid) hormones, including the pyramidal cells of Ammon's horn and granule cells of the dentate gyrus (Gerlach and McEwen,1972; Cameron and Gould, 1996, Drekic et al. 1998). Hippocampal estrogen receptors (ER) mRNA levels increased significantly between birth and P4 where peak concentrations were found and than declined by P10. This suggests that the ontogeny of ER in the hippocampus is regulated by alterations in ER gene expression in specific neonatal populations. The postnatal rat hippocampus may be sensitive to estrogenic and testosterone trophic and organizational influence during a "critical period" of sexual differentiation (O'Keefe et al., 1995). It is thought that testosterone and its metabolites sensitize an androgen-responsive system, while estrogenic metabolites establish the capacity to light in response to estrogenic stimulation later in life. Despite this, testosterone is only one of a myriad of factors that influence aggression and the effects of previous experience and environmental stimuli have at times been found to correlate more strongly (Simpson 2001). Estradiol increases spine density on rat hippocampal CA1 pyramidal cells (Wooley and McEwen, 1993). There are not related data for dentate gyrus. The presence of labeled cells indicates the existence of DNA replication in investigated regions in the neonatal period (Drekic et al., 1990; $1995 a, b)$. DOI overcome the neonatal androgen effect in suppressing the positive feedback of ovarian steroids in a few males and androgenized females. DOI had a feminizing effect on the volume of the anteroventral periventricular nucleus (normally smaller in males, by significantly increasing its volume in male and androgenized females. It also had a significant antagonistic effect on the testosterone-induced increase in the volume of the sexually dimorphic nucleus of the preoptic area in males and androgenized females. These findings support the evidence that raised 5-HT activity in the second week of life antagonizes the masculinizng effect of neonatal testosterone (Siddiqui et al. 2004).

In males, neonatal orchidectomy increased beta relative power, whereas both neonatal and adult castration reduced interparietal correlation. In females, 
prenatal testosterone administration produced higher theta absolute power; theta relative power was higher in all experimental groups, whereas beta I and beta 2 were decreased by prenatal and increased by neonatal virilization; prenatal virjlization enhanced, while neonatal virilization and adult ovariectomy decreased interparietal correlation. These data indicate that females are more sensitive to early prenatal than to neonatal organizational effects of sex steroids, and some electroencephalographic features are feminized in castrated males and virilized in perinatally androgenized females (Corsi-Carbera et al., 2000).

With the exception of the greatest increase of labeled cells being in SGZ of both limbs, the other layers of dentate gyrus react differently. The number of labeled neurons in suprapyramidal limb GZ was unchanged, and in EGZ was increased, while in infrapyramidal limb GZ it was significantly increased. The number of labeled neurons in EGZ was increased in both suprapyramidal and infrapyramidal regions. This difference between suprapyramidal ("less sensitive" in that period of development) and infrapyramidal limb is well related to described neurogenetic gradients in development (Bayer, 1980) and cell death process in the dentate gyrus (Gould et al., 1991). Also, in x-ray irradiated rats at P1 the dorsal blade of dentate gyrus was reduced but however still present and the ventral blade was entirely missing or rudimentary (Czurko et al., 1997). In our experiment the number of labeled cells was not significantly change in the GZ of the suprapyramidal limb. Considering this fact, as well as different quantitative relationships in reaction to estrogen in different layers of the supra- and infrapyramidal limb, which reacted by an increase in the number of labeled cells, we can conclude that these two regions of the dentate gyrus and their zones react differently to administered estradiol in neonatal male rats. Generally we can conclude that estradiol increased ${ }^{3} \mathrm{H}$-thymidine incorporation in deoxyribonucleic acid (DNA) of hippocampus dentate gyrus granule cells in the neonatal male rats. Furthermore, our findings suggest very fine specific local differences in proliferation and differentiation of nerve cells inside hippocampal dentate gyrus in early postnatal days caused by the influence of estrogene (Drekić et al., 1998).

We have noticed that females treated with $2 \mathrm{mg}$ of TP in their 4th and 8th day of life experience smaller damages in sub granular layer of SGZ than females treated with $4 \mathrm{mg}$ of TP at 15 a days of age. Female rats treated with two doses of TP on the 4th and 8th day of their neonatal life there are no important damages in SGZ GS, but the opposite is noticed in the case of female rats treated with one higher dose of TP at 15 days of neonatal life. This is where we have noticed a great number of degenerated glya cells and neurons in SGZ both parts of GD.

Address for correspondence:

Prof. dr Dmitar Drekić

Department of Anatomy

Faculty of Veterinary medicine,

Bulevar oslobođenja 18,

11000 Belgrade, Serbia \&Montenegro

e-mail: dmitar@vet.bg.ac.yu 


\section{REFERENCES}

1. Arnold AP, Gorski RA, 1984, Gonadal steroid induction of structural sex differences in the central nervous system, Ann Rev Neurosci, 7, 413-42.

2. Bayer $S A, 1982$, Changes in the total number of dentate granule cells in juvenile and adult rats, $A$ correlated volumetric and 3H- thymidine autoradiographic study, Exp Brain Res, 46, 315-23.

3. Bayer SA, Altman J, 1974, Hippocampal develoment in the rat: Cytogenesis and morphogenesis examined with autoradiography and low- level x-irradiation, J Comp Neurol, 158, 55-80.

4. Bayer SA, 1980, Development of the hippocampal region in the rat, II, Morphogenesis during embryonic and early postnatal life, $J$ Comp Neurol 190, 115-34.

5. Bayer SA, Yakel JW, Puri PS, 1982, Neurons in the rat dentate gyrus granular layere substantially increase during juvenile and adult life, Science, 2176, 890-92.

6. Cameron HA, Gould E, 1996, Distinct population of cells in the adult dentate gyrus undergo mitosis or apoptosis in response to adrenalectomy, J Comp Neurol, 369, 56- 63.

7. Cameron HA, Mc Ewen BS, Gould E, 1995, Regulation of adult neurogenesis by excitatory input and NMDA receptor activation in the dentate gyrus, $J$ Neurosci, 15, 4687-92.

8. Corsi-Cabrera M, Ugalde E, DEI-Rio-Portilla, Fernandez-Guasti A, 2000. Organizational and activational effects of gonadal steroid hormones on the EEG of male and female rats, Developmental Psychobiology, 37, 3, 194-7

9. Crespo DB, Stanfield B, Cowan WM, 1986, Evidence that late - generated granule cells do not simply replace earlier formed neurons in the rat dentate gyrus, Exp Brain Res, 62, 541-48.

10. Czurko A, Czeh B, Seress L, Nadel L, Bures J, 1997, Severe spatial navigation deficit in the Morris water maze after single high dose of neonatal $\mathrm{x}$ - ray irradiation in the rat, Proc Acad Sci USA, 94, 2766-72.

11. Cvetković D, 1995, Uticaj polnih steroida na Nucleus basomedialis Corpus amygdaloideum, Doktorska disertacija, Veterinarski fakultet, Beograd.

12. Drekić D, Malobabić S, Gledić D, Cvetković D, 1995a, Different neuronal and glial celll groups in corticomedial amygdala react differently to neonatally administered estrogen, Neurosci, 66, 475-81.

13. Drekić $D$, Gledić $D$, Malobabić S, Šimić $M, 1990$, Study of cells in amygdala of rats neonatally treated with estrogen, Verh Anat Ges, 83 Anat Anz Suppl,166 499-00.

14. Drekić D, Malobabić S, Cvetković D, Lozanče O, 1995b, Study of neurons and glial cells of basolateral amygdala in male and female rats neonataly treated with estrogen, Int $J$ Neurosci, 83, 145-51.

15. Drekić $D$, Malobabić S, Gledić $D$, Lozanče O, Djelić $D$, 1998, Study of dentate gyrus granule cells of male rats neonataly treated with estrogen, Acta veterinaria, 48, 5-6, 277-88

16. Duffy CJ, Rakić P, 1983, Differentiation of the granule cells in the dentate gyrus of the rhesus monkey: A quantitative Golgi study, J Comp Neurol 214, 225-32.

17. Gazzaley AH Weiland NG, McEwen BS, Morrison JH, 1996, Differential regulation of NMDAR MRNA and protein by estradiol in the rat hippocampus, $J$ Neurosci, 16, 6830-38.

18. Gerlach J, Mc Ewen B, 1972, Rat brain binds adrenal steroid hormone Radioautography of hippocampus with corticosterone, Science, 1975, 1133-6.

19. Gould E, Wooley CS, Mc Ewen BS, 1991, Naturally occuring cell death in the developing dentate gyrus of the rat, $J$ Comp Neurol, 304, 408-418.

20. Jaarsma $D$, Postema F, Korf J, 1992, Time course and distribution of neuronal degeneration in the dentate gyrus of rat after adrenalectomy: a silver impregnation study, Hippocampus, 2, 143-50.

21. Kuhn HG, Dickinson-Ansons H, Gage FH, 1996, Neurogenesis in the dentate gyrus of the adult rat: aged related decrease of neuronal progenitor proliferation, $J$ Neurosci, 16, 2027-33.

22. Lozanče O, 1995, Uticaj progesterona na neurone amigdaloidnog kompleksa mužjaka i ženki pacova treiranih u neonatalnom i kasnom juvenilnom periodu, Doktorska disertacija, Veterinarski fakultet, Beograd.

23. Nordeen EJ, Nordeen KW, Sengelaub DR, Arnold AP, 1985, Androgens prevent normally occuring cell death in a sexually dimorphic spinal nucleus, Science, 299, 671-3. 
24. Nowakowski R, Rakić P. 1981, The site of origin and route and rate of migration to the hippocampal region of the rhesus monkey, J Comp Neurol, 196, 129- 54

25. O'Keffe JA, Li Y, Burgess LH, Handa RJ, 1995, Estrogen receptor mRNA alterations in the developing rat hippocampus, Brain Res Mol Brain Res 30, 115-24.

26. Pantić V, Drekić D, 1982, Long term effects of oestrogen on cells of corpus amygdaloideum nuclei, Acta Veterinaria, Beograd, 32, 2-3, 79-90.

27. Parent JM, Yu WT, Leibowitz R, Geschwind DH, Sloviter RS, Lowenstein D, 1997, Dentate granule cells neurogenesis is increased by seizures and contributes to abberrant network reorganization in the adult rat hippocampus, $J$ Neurosci, 17, 3727-38.

28. Rua C, Trejo JL, Machin C, Arahuetes RM, 1995, Effects of maternal adrenalectomy and glucocorticoid administration on the development of rat hippocampus, J Hirnforsch, 36, 47383.

29. Seki T, Arai Y, 1995, Age -related production of new granule cells in the adult dentate gyrus, Neuroreport 6, 2479-82.

30. Sidman RL, Rakić P, 1982, Development of the human central nervous system in Cytology and Cellular Neuropathology, $2^{\text {nd }}$ ed., 3-145, CC Thomas, Springfield, IL.

31. Siddiqui A, Murray JF, Wilson CA, 2004, Relationship between neonatal testosterone and 5 hydroxytryptamine $(5-\mathrm{HT})$ in controlling the pattern of $\mathrm{LH}$ release in adult rats, Iranian $J$ Pharm Res, Abstracts of lectures, 1, 15.

32. Simpson K, 2001, The Role of Testosterone in Aggression. McGill Journal of Medicine, 6, 32-40

33. Teyler Y, Vardaris TRM, Lewis D, Rawiteh AB, 1980, Gonadal Steroids Effection Excitability of Hippocampal Pyramidal Cells, Science, 209, 1017-9.

34. Watanabe Y, Weland NG, McEwen BS, 1995, Effects of adrenal steroids manipulations and repeated restraint stress on dynorphin mRNA levels and excitatiory amino acid receptor binding in hippocampus, Brain Res 680, 217-25.

35. Woolley C, Mc Ewen BS, 1993, Roles of estradiol and progesterone in regulation of hippocampal dendritic spine density during the estrous cycle in the rat, J Comp Neurol, 336, 293-06.

\title{
IZUČAVANJE PROLIFERACIJE ZRNASTIH ĆELIJA GIRUS DENTATUSA NEONATALNIH ŽENKI PACOVA TRETIRANIH POLNIM HORMONIMA
}

\author{
DREKIĆ D, MRVIĆ VERICA, LOZANČE OLIVERA, KERKEZ M, BLAGOJEVIĆ M i ZORIĆ Z
}

\section{SADRŽAJ}

Proliferacija zrnastih ćelija gyrus dentatus-a izučavana je ugrađivanjem ${ }^{3} \mathrm{H}$ timidina kod kontrolnih i estrogenom tretiranih pacova. Novorođene, tri dana stare ženke pacova Wistar soja, tretirane su jednom dozom od $1 \mathrm{mg}$ estradiola i sa 80 $\mu \mathrm{Ci}{ }^{3} \mathrm{H}$-timidina, a žrtvovane su 38. dana.

Izučavanjem gyrus dentatus-a hipokampusa ženki pacova tretiranih estrogenom ustanovljen je povećan broj obeleženih zrnastih celija u granularnom sloju. U infrapiramidalnom delu, povećanje broja obeleženih ćelija u tretiranih životinja, bilo je značajno u svim zonama granularnog sloja. U suprapiramidalnom delu granularnog sloja, značajan porast broja obeleženih ćelija je dokazan je samo u supragranularnoj (SGZ) i ekstragranularnoj zoni (EGZ). 
Naši rezultati ukazuju da postoji specifičan efekat estradiola na proliferaciju zrnastih ćelija gyrus dentatus-a tokom ranog razvoja kod pacova.

Ustanovljeno je da ženke tretirane 4. i 8 dana života sa po 2 mg TP imaju manja ostećenja u subgranularnom sloju SGZ, u odnosu na ženke tretirane 15. dana života sa 4 mg TP u GD. Kod ženki pacova tretiranih sa dve doze TP 4. i 8. dana neonatalnog života nema većih ostećenja u SGZ GD, kao sto je to slučaj kod ženki tretiranih 15. dana kasnog neonatalnog života sa jednom velikom dozom TP u SGZ oba dela GD. U tom periodu je ustanovljen veliki broj degenerisanih glija ćelija i neurona u SGZ oba dela GD. Ovi rezultati navode na zaključak da postoje različiti efekti polnih hormona na gyrus dentatus granularnih ćelija čija se proliferacija odvija u neonatalnom periodu života pacova. 